\section{Ks. Sławomir Stasiak}

Papieski Wydział Teologiczny we Wrocławiu e-mail: gimel@poczta.onet.pl

DOI: http://dx.doi.org/10.12775/BPTh.2015.008

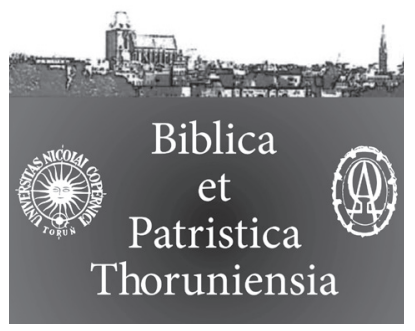

8 (2015) 2 ISSN 1689-5150

\title{
Czy ustrój patriarchalny mógł sprzyjać przemocy wobec kobiety?
}

\author{
Is the patriarchal system \\ could foster violence against women?
}

Streszczenie. Przekonanie o tym, że patriarchat mógł sprzyjać przemocy wobec kobiety, jest dość powszechnie przyjmowanym paradygmatem, zwłaszcza w odniesieniu do społeczeństw, które odczuwały związek z nauczaniem Biblii. Musimy więc zadać sobie przede wszystkim pytanie: Czy znajdujemy w tekstach biblijnych podstawy do takiego osądu? A następnie: Czy właściwie rozumiemy te teksty, które zdają się sugerować dominację mężczyzny nad kobietą? I jeszcze: Na ile na nasze postępowanie ma wpływ nauczanie Biblii, a na ile jest to wynik uwarunkowań społecznych, które ukształtowały się niezależnie od pierwotnego źródła, lub wręcz w opozycji do niego? Jako podstawę odpowiedzi na postawione pytania wzięliśmy trzy teksty biblijne, jeden ze Starego Testamentu (Rdz 1,26-27; 2,7.21-23) i dwa z nowego (1 Kor 14,33b-35 i 1 Tm 2,11-15). Z poczynionych badań wynika, że już w Księdze Rodzaju zauważamy rewolucyjne zmiany, graniczące wręcz ze swego rodzaju rewolucją społeczną. Oto okazuje się, że zarówno w tekście pochodzącym z X w. przed Chr. (Rdz 2,7.21-23), jak i w tym z ok. V w. przed Chr. (Rdz 1,26-27) kobieta w niczym nie ustępuje mężczyźnie. Jest mu całkowicie równa. Obserwując zaś sytuację w Koryncie, na którą Paweł reaguje w bardzo zdecydowany sposób (1 Kor 11,2-16; 14,33b-36), wydaje się, że znów wszystko wraca do „normy”, na rzecz dominacji mężczyzny. Tymczasem tak nie jest. Po pierwsze, reakcja na konkretną sytuację, to znaczy domaganie się od kobiet możliwości wypełniania funkcji kultycznych. Po drugie, uwagi dotyczące zachowania kobiety i mężczyzny w czasie liturgii, zawierają w sobie model idealnego ucznia (kobieta) i idealnego nauczyciela (mężczyzna). Jak wiemy, uczeń słucha tak długo, jak długo jest uczniem. Kiedy przestaje nim być, wówczas przestaje milczeć i stając się nauczycielem, zaczyna mówić. Podobnie rzecz ma się ze wskazaniami zawartymi w 1 Tm 2,11-15. Kobieta jako matka i żona posiadała jasno określoną i uprzywilejowaną pozycję w małżeństwie i w rodzinie. Nie mogła jednak tej pozycji przenosić na zgromadzenie liturgiczne, nawet jeśli odbywały się one w domu, którego właścicielem był jej mąż. Ostateczny wniosek więc jest taki, że patriarchat, jakkolwiek mocno zakorzeniony w judaizmie i z niego zaczerpnięty przez chrześcijaństwo, niekonieczne musi sprzyjać deprecjonowaniu pozy- 
cji kobiety w życiu społecznym. Analizowane teksty wskazują raczej na pozycję równą mężczyźnie, jakkolwiek każdy i kobieta, i mężczyzna posiadają sobie właściwą pozycję w zgromadzeniu liturgicznym, zależnie od otrzymanych charyzmatów.

Abstract. The belief that patriarchy could foster violence against women is pretty widely adopted paradigm, especially in regard to societies that feel relationship with the teachings of the Bible. So we have to ask ourselves first and foremost question: Is the biblical texts where we can find grounds for such a judgment? And then: Do we properly understand these texts that seem to suggest the dominance of man over woman? And again: How much of our behavior is influenced by the teaching of the Bible, and to what extent this is the result of social conditions that shaped independently from the original source, or even in opposition to it? As the basis for answers to these questions we took three biblical texts, one from the Old Testament (Gen 1:26-27; 2:7.21-23) and two from the new one (1 Co 14:33b-35 and 1Tim 2:11-15). The research shows that in Genesis we see a revolutionary change, bordering almost with a kind of social revolution. Here it turns out that both in the text dating from the X c. BC. (Gen 2:7.21-23) and in that of approx. V in. BC. (Gen 1:26-27) a woman is not inferior to a man in anything. They are completely equal. Observing the situation in Corinth, to which Paul responds in a very decisive manner (1 Co 11:2-16;14:33b-36), it seems that once again everything goes back to "normal" for the domination of man. However, it is not. Firstly, in response to a specific situation, that is demanding from women fulfilling their cultic functions. Secondly, the comments concerning the behavior of women and men in the liturgy contain a model of an ideal disciple (female) and an ideal teacher (male). As we know, the student listens as long as is a disciple. When he ceases to be a disciple, he ceases to remain silent and becoming a teacher starts talking. The same applies to the indications included in 1 Tim 2:11-15. The woman, as a mother and wife had a clearly defined and privileged position in marriage and family. But she could not move this position to liturgical assembly, even if they took place in the house, which was owned by her husband. So the final conclusion is that patriarchy, although firmly rooted in Judaism and from there taken by Christianity, does not have to foster depreciating of the position of women in society. The analyzed texts tend to support the position equal to man, although both a woman, and a man have their proper position in the liturgical assembly, according to the received charisms.

Słowa kluczowe: stworzenie człowieka; patriarchat; święty Paweł; zgromadzenie liturgiczne; kobieta i mężczyzna; żona i mąż; przemoc wobec kobiet.

Keywords: the creation of man; patriarchy; saint Paul; the liturgical assembly; woman and man; wife and husband; violence against women. 
W

pływ patriarchatu na przemoc wobec kobiety jest dość powszechnie przyjmowanym paradygmatem, zwłaszcza w odniesieniu do wszystkich społeczeństw, które odczuwają związek z nauczaniem Biblii. Musimy zadać sobie przede wszystkim pytanie: Czy znajdujemy w tekstach biblijnych podstawy do takiego osądu? A następnie: Czy właściwie rozumiemy te teksty, które zdają się sugerować dominację mężczyzny nad kobietą? I jeszcze: Na ile nauczanie Biblii ma wpływ na nasze postępowanie, a na ile jest to wynik uwarunkowań społecznych, które ukształtowały się niezależnie od pierwotnego źródła, lub wręcz w opozycji do niego? Jak na przykład Konwencja Rady Europy o przeciwdziałaniu $i$ zwalczaniu przemocy wobec kobiet i przemocy domowej posługując się terminem „religia” robi przedwstępne założenia: „Strony gwarantują, że kultura, zwyczaje, religia, tradycja czy tzw. „honor” nie będą uznawane za usprawiedliwienie dla wszelkich aktów przemocy objętych zakresem niniejszej Konwencji” (art. 12). Bez wskazania konkretnej religii, która miałaby być źródłem przemocy wobec kobiet, należy wnosić, że dotyczy to wszystkich wyznań. Religia chrześcijańska nie jest tym czynnikiem, który sprzyja nierówności kobiet, czy przemocy wobec nich. Z tym absolutnie nie można się zgodzić, co zresztą zostało bardzo zdecydowanie podkreślone przez Konferencję Episkopatu Polski już w lipcu 2012 r. Na postawione wyżej pytania postaramy się udzielić odpowiedzi, sięgając do trzech tekstów. Jeden ze Starego Testamentu (Rdz 1,26-27; 2,7.21-23), a dwa z Nowego (1 Kor 14,33b-35 i 1 Tm 2,11-15).

\section{Opisy stworzenia mężczyzny i kobiety}

Znajdujemy go oczywiście w opisie stworzenia świata i człowieka ( $\mathrm{Rz} 1,1-2,4 \mathrm{a})$ oraz w opisie rajskiej egzystencji człowieka (2,4b-25).

Przy stwarzaniu roślin i zwierząt lądowych Bóg mówi: „niech ziemia wyda” $(1,24)$, a przy stwarzaniu elementów natury (sklepienie, słońce, księżyc) Bóg mówi po prostu: „niech się staną” $(1,1,3.6)$. To stworzenie człowieka zostało poprzedzone formułą: „I rzekł Bóg: Uczyńmy człowieka” - wajjōmer ělōhîm na 'áśeh 'ādām (1,26). Ważnym elementem tej narracji jest użyta w tym wersecie liczba mnoga „uczyńmy” (na ǎśseh), „na nasz obraz” (becalemēnû), „podobnego nam" (kidemûtēnû). Ze składni hebrajskiej wiemy, że imię Boże ělōhîm łączy się z orzeczeniem zarówno w singularis, jak i pluralis, zawsze jednak w sensie singularis, o ile oczywiście ’̌lōhîm oznacza Boga Izraela. Tak również mamy w naszym tekście: „I rzekł ělōhîm (singularis): uczyńmy (pluralis)”. Pomijając opinie w rodzaju, że jest to jakiś ślad dawnego politeizmu, przyjmujemy za większością egzegetów, że jest to tzw. pluralis deliberationis: „Bóg się zatrzymuje: nie słowo rozkazu, lecz słowo refleksji. [...] W tym momencie chce 
się wyrazić w sposób szczególny, że teraz Bóg zmierza do spełnienia swego najgłębszego zamysłu"1. Dla nas ważnym wnioskiem, który wyciągnął z tej wypowiedzi T. Brzegowy, że Bóg koncentruje się i konsultuje samego siebie albo radzi się dworu niebieskiego (por. $1 \mathrm{Krl} 22,19-22$; Hi 1,6 itd.) ${ }^{2}$. Zatem Bóg, przystępując do ostatniego dzieła, podejmuje je ze szczególną uwagą. To jednak nie wyjaśnia nam jeszcze postawionego problemu. Nieco więcej światła mogą rzucić na omawiane zagadnienie kolejne słowa: „niech panują” ( $\left.w^{e} j i r^{e} d \hat{u}\right)$. Gdyby była mowa o pojedynczej osobie, co sugerowałoby wyrażenie 'ādām, to również rdzeń $r d h$ winien być użyty w trzeciej osobie liczby pojedynczej, a nie jak tutaj w trzeciej osobie liczby mnogiej. Czy zatem autorowi natchnionemu chodziło o mężczyznę i kobietę i dlatego posłużył się liczbą mnogą? Rzeczownik 'ādām został użyty w liczbie pojedynczej, lecz jego znaczenie jest zbiorowe: „rodzaj ludzki, ludzie” albo „mężczyzna i kobieta”. Nie wchodząc w inne dyskusje na temat etymologii, które nie są przedmiotem naszych poszukiwań, stwierdźmy jedynie, że termin 'ādām pozostaje w ścisłym związku z ă 'dāmāh, „ziemia”, z której został uformowany człowiek (zob. Rdz 3,23) i w takim ujęciu nazwa Adam znaczyłaby tyle, co „ziemski, człowiek, stworzenie”. Więcej światła na zagadnienie niezgodności gramatycznej rzucają słowa o realizacji Bożego planu: „I stworzył Bóg człowieka na swój obraz, na obraz Boży go stworzył: mężczyzną i niewiastą stworzył ich" $(1,27)$. Jest to rytmiczne zdanie składające się z trzech członów, z których nas najbardziej interesują pierwszy (wajjiberāh 'élōhîm 'et-hāādām) i ostatni (zākār ûn kēbāh bārā' ōtām). Bóg zatem stworzył człowieka, co nie zaskakuje, biorąc pod uwagę wcześniej przedstawiony plan. Jednak jego realizacja nie dotyczy jedynie płci: $z \bar{a} k \bar{a} r$ (istota męska) i $n^{e} q \bar{e} b \bar{a} h$ (istota żeńska). Jakkolwiek płciowość człowieka jest sama w sobie rzeczą dobrą, gdyż pochodzi od Boga i nosi na sobie ślady Bożej potęgi stwórczej. H. Haag zauważa, że podobieństwo Boże w człowieku jest nierozdzielne z płciowością. Obie prawdy zostały wypowiedziane jednym tchem. Mężczyzna i kobieta złączeni, odbijają obraz Boży tak jak zjednoczeni przedłużają stworzenie. W całym fragmencie Rdz 1,26-31, od samego początku kobieta została ukazana jako równa w godności partnerka mężczyzny. W takim samym stopniu odbija obraz Boży. Jawi się to na tle ówczesnej literatury bliskowschodniej jako niesłychana nowość teologiczna. Obie płcie są równie godne, gdyż obie są stworzone „na obraz Boży”. Płciowość jest integralną częścią dzieła, które sam stwórca nazwał „bardzo dobrym” - tôb me’òd (Rdz 1,31)3. Opowieść zatem o stworzeniu Adama i Ewy jest narracją o człowieku, o jego początku na ziemi. Tę samą myśl

1 Por. W. Zimmerli, 1. Mose 1-11, s. 76.

2 Por. T. Brzegowy, Pięcioksiag Mojżesza, s. 126.

3 Por. H. Haag, Schöpfungsbericht, s. 1554. 
wyraził analizowany przez nas tekst Rdz 1,1-2,4a stwierdzeniem: „Tak stworzył Bóg człowieka” - wajjiberāh ělōhîm 'et-häādām (Rdz 1,27).

W ramach narracji o rajskiej egzystencji człowieka (2,4b-25) Jahwista opowiada o poszukiwaniu najlepszej pomocy dla mężczyzny ( $\operatorname{Rdz} 2,18-20)$. Spośród wszystkich stworzeń godnością Adamowi odpowiada dopiero Ewa ( $\operatorname{Rdz} 2,21-23$ ). Jednak stwierdzenie, że została stworzona z żebra Adama bywa interpretowane negatywnie. Nie jest to motyw wyłącznie chrześcijański. Motyw żebra, z którego Jahwe uczynił Ewę, wskazuje na dużo starszy niż biblijny mit mezopotamski mit Enki i Ninhursag. „Enki i Ninhursag - mit o raju (Dilmun). Sumerowie stworzyli nie tylko „rajskie” warunki życia na ziemi, które pociągały wiele koczujących plemion, lecz nadali im cechy boskie. Mit o Dilmun opiewa miejsce przeznaczone wyłącznie dla bogów. Śmiertelni nie mają wstępu do raju, czystej i jasnej krainy bogów. Nieznane były tam choroby ani śmierć, ale nie było odpowiedniej wody, potrzebnej roślinom i zwierzętom; zapewnił ją dopiero bóg słońca, Utu na prośbę Enki, boga wód. Niezwykła obfitość wód zmieniła boski ogród w raj - podobnie jak sieć kanałów nawadniających przekształciła Sumer w kraj dobrobytu. „Bez bólu i trudu” ze związku Enki i Ninhursag rodzi się Ninmu, która staje się matką Ninkury, ta zaś daje życie bogini Uttu. Wszystkie boginie rodzą się z nasienia Enki. Także do Uttu udał się on w zaloty, przynosząc jej w darze ogórki, jabłka i winogrona. Tym razem Ninhursag sprawiła, że z nasienia Enki wyrosło osiem różnych gatunkowo roślin. Isimud, wysłannik Enki, zerwał je dla niego. Pragnienie Enki okazało się tym razem głębsze: wyrażało jego wolę, by decydować o losie tych roślin, poznać ich „serce”. Tego było już za wiele! Toteż Ninhursag rzuciła nań urok. Choremu Enki nie był w stanie pomóc nawet sam Enlil, najpotężniejszy z bogów. Trzeba było sprowadzić rozgniewaną Ninhursag. Sztuki tej dokonał lis. Udobruchana Ninhursag stworzyła osiem bóstw, które uleczyły osiem chorych miejsc Enki. Między innymi bogini Nin-ti, pani żebra, uzdrowiła jego żebro. „Ti” oznacza także życie! A zatem Nin-ti to również pani dająca życie, życiodajna matka sumeryjska Ewa"4.

Warto jeszcze zwrócić uwagę na słowa, które wypowiada mężczyzna, kiedy Bóg przyprowadza mu kobietę: „Ta dopiero jest kością z moich kości i ciałem z mego ciała. Ta będzie się zwała niewiastą, bo ta z mężczyzny została wzięta. Dlatego to mężczyzna opuszcza ojca swego i matkę swoją i łączy się ze swoją żoną tak ściśle, że stają się jednym ciałem" (Rdz 2, 23-24). Adam odczuwał w raju udrękę samotności. Lecz Jahwista nie upatruje szczęścia mężczyzny w zmysłowości. Niewiasta ma go wspomagać, choć nie na sposób służącej czy niewolnicy. Godność kobiety jest dyskretnie zaznaczona w dwóch sformuło-

4 T. Hergesel, Rozumieć Biblię, s. 13. 
waniach: „Nie jest dobrze, żeby mężczyzna był sam” (lō’ tôb hějôt hāādām $l^{l^{-}}$ baddô; Rdz 2,18), „mężczyzna opuszcza ojca swego i matkę swoją i łączy się ze swoją żoną" ( 'al-kēn ja 'ăzāb-'îš 'et-'ābîw we'et-'immô; Rdz 2,24). Pomiędzy mężczyzną a kobietą istnieje wzajemna zależność, dlatego jedno nie ma tytułu do wywyższania się nad drugie. Subtelną uprzejmość widać w stwierdzeniu, że to mężczyzna łączy się ze swoją żoną, a nie odwrotnie! Ponadto mężczyzna

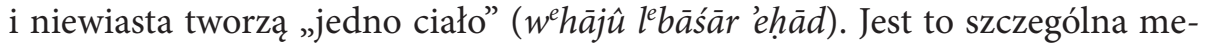
tafora jedności i nierozerwalności małżeństwa, co potwierdził swoim autorytetem Jezus (Mt 19,3-9), odwołując się do sytuacji „na początku”. Mojżeszowy list rozwodowy to sprawa późniejsza. Z nauczania Jezusa wynika, że Jahiwsta ukazał istotę małżeństwa według zamiarów Stwórcy, to znaczy, że ma być ono jak najściślejszą więzią ducha i ciała, dozgonną jednością obojga małżonków. Miłość małżeńska ma nie tylko zapewnić biologiczny rozwój ludzkości, lecz także ma być podstawą życia w rodzinie. „Jedno ciało” to metafora jedności życia, wspólnoty celu i wzajemnej pomocy. Nie ma tu mowy ani słowem o typowym wówczas podporządkowaniu kobiety mężczyźnie. Dla Jahwisty małżonkowie są równorzędnymi osobami. Zakładał on również zasadniczą zgodność pomiędzy nimi jako właściwe odniesienie, natomiast egoizm, agresywność czy poczucie wstydu wiązał z popełnionym grzechem ${ }^{5}$. Podziwiać trzeba Jahwistę za przyznanie kobiecie tak niezwykle wysokiej rangi społecznej. Widocznie cieszyła się nią w monarchii Dawida i Salomona. Jeszcze w Dekalogu kobieta jest wymieniona jako własność - na pierwszym miejscu wprawdzie, ale w jednym szeregu z niewolnikiem, wołem, osłem, a nawet rzeczą (Wj 20,17).

Oba opisy stworzenia człowieka (1,1-2,4a i 2,4b-25) podkreślają zgodnie choć posługują się innym językiem - wyjątkowość człowieka na tle całego stworzenia: tylko w Adamie tkwi pierwiastek samego Boga. Bóg obdarzył człowieka cząstką samego siebie. W Rdz 1,27 myśl ta została wyrażona stwierdzeniem, że Bóg stworzył człowieka na swoje „podobieństwo”, na swój „obraz”. W Rdz 2,7 mowa jest o tym samym, ale językiem plastycznym; ukazując Stwórcę, który ukształtowaną z materii nieożywionej postać ludzką obdarza życiodajnym tchnieniem. Wszystko to dotyczy „Adama”, co nie oznacza, że jedynie mężczyzny, lecz także i to w równym stopniu kobiety.

\section{O zachowaniu się kobiet w czasie zgromadzenia}

Wielka powaga, z jaką Paweł omawia zagadnienie stroju kobiet w czasie zgromadzenia liturgicznego (1 Kor 11,2-16), sugeruje, że nie chodziło jedynie o tak

5 Por. ibidem, 184-190. 
banalny detal. Rzecz dotyczyła czegoś dużo bardziej istotnego dla chrześcijan w Koryncie. Pojawił się tam, jak można przypuszczać, swego rodzaju ruch feministyczny, który domagał się dla kobiet funkcji ściśle kultycznych. Paweł $\mathrm{w}$ tej kwestii zajmuje jednoznaczne stanowisko, co nie znaczy, że jest przeciw równości mężczyzn i kobiet (por. Ga 3,28). Recz w tym, aby równość ta była właściwie pojmowana. Wszyscy muszą być podporządkowani przewodniczącemu liturgii: „Tak jak to jest we wszystkich zgromadzeniach świętych, kobiety mają na tych zgromadzeniach milczeć; nie dozwala się im bowiem mówić, lecz mają być poddane, jak to Prawo nakazuje. A jeśli pragną się czego nauczyć, niech zapytają w domu swoich mężów! Nie wypada bowiem kobiecie przemawiać na zgromadzeniu. Czyż od was wyszło słowo Boże? Albo czy tylko do was przyszło?" (1 Kor 14,33b-36).

Podane zostają kolejne zasady dotyczące zachowania kobiet w zgromadzeniu. Pawłowa regulacja dotycząca roli kobiet we wspólnocie Kościoła w Koryncie pozostaje $\mathrm{w}$ zgodzie $\mathrm{z}$ normami dotyczącymi wszystkich Kościołów. Wyrażenie „zgromadzenia świętych” (hai ekklēsiai tōn hagiōn) należy rozumieć jako wszystkie Kościoły chrześcijańskie, bo „święci” (hoi hagioi), to wszyscy ochrzczeni (por. 1 Kor 1,2$)^{6}$. Nie chodzi więc o jakąś okazjonalną normę podyktowaną zaistniałą, szczegółową sytuacją. Pozostaje ona w zgodzie z postawioną kilka wersetów wcześniej zasadą o unikaniu zamieszania i nieporządku. Zasada ta bowiem powtarza strukturę dwóch poprzednich reguł: ogólna norma (ww. 33b-34), rozwiązanie konkretnego przypadku (w. 35) i motywacja (w. $36)^{7}$. Ogólna zasada dotyczy milczenia kobiet w czasie zgromadzeń. Jakkolwiek kobiety, podobnie jak i mężczyźni mogą posiadać charyzmat proroctwa (por. 11,5.13). Paweł przedstawia tę zasadę jako wywodzącą się z Prawa, robiąc aluzję albo do Rdz 3,16, albo do Lb 12,1-5. Nakaz milczenia kobiet dotyczył świątyni jerozolimskiej i nabożeństw, które odbywały się w synagogach ${ }^{8}$. Temat poddania przywołuje kontekst rodzinny. O ile kobieta, mniej wykształcona w owych czasach niż mężczyzna, w zgromadzeniu winna milczeć, o tyle w domu może zwrócić się do męża, jako głowy rodziny, z prośbą o wyjaśnienie. Wydaje się, że mamy tu do czynienia z pewnym modelem opartym na relacji: mistrz-uczeń. O ile mężczyzna jest tu wzorcem mistrza, o tyle kobieta jest modelem ucznia, który w zgromadzeniu słucha, a w domu prosi o ewentualne wyjaśnienia ${ }^{9}$. Nakaz milczenia kobiet można wyjaśnić jeszcze inaczej. Paweł mógł się oprzeć na dwuznaczności terminów gynē („kobieta, żona”) i anēr („mężczyzna, mąż”).

6 Por. J. Czerski, Pierwszy List do Koryntian, s. 645,

7 R. Fabris, Prima Lettera ai Corinzi, s. 186.

8 Por. J. Czerski, Pierwszy List do Koryntian, s. 646.

9 Por. S. Stasiak, Komentarz, s. 493. 
W zgromadzeniu kobieta powinna okazywać mężowi posłuszeństwo, w domu zaś, jako żona, ma pewien autorytet i władzę nad członkami rodziny, właśnie z racji obowiązków i praw, jakie przysługiwały żonie. Można przypuszczać, że spotkania wspólnoty Kościoła, zwłaszcza te o charakterze modlitewnym, odbywały się w Koryncie w domach prywatnych. Mogło się zatem zdarzyć, że kobieta chciała zabierać głos na zgromadzeniach liturgicznych odbywających się w domu, w którym ona była matką i żoną jego właściciela. Niewykluczone, że to dotyczyło także innych kobiet, które zgromadzenie to traktowały jako spotkanie prywatne. W domu przysługiwały jej prawa małżonki i matki, Paweł jednak uważa takie zgromadzenie za publiczne, czy nawet liturgiczne i dlatego nakazuje kobietom milczenie ${ }^{10}$.

$\mathrm{Na}$ zakończenie norm dotyczących zachowania kobiet w zgromadzeniu, Paweł stawia dwa pytania retoryczne skierowane do Koryntian (w. 36). Nie zostały one skierowane do kobiet, lecz do całej wspólnoty Kościoła w Koryncie, na co wskazuje przejście z trzeciej na drugą osobę liczby mnogiej. Apostoł zatem powraca do normy ogólnej postawionej w 2,33 oraz do zasadniczego tematu rozdziału czternastego, czyli do zagadnienia korzystania z charyzmatów na zgromadzeniach liturgicznych ${ }^{11}$. Na postawione pytania, które mają charakter retoryczny, oczekiwana jest odpowiedź negatywna, bowiem to nie od Koryntian wyszło „słowo Boga” (ho logos tou Theou), lecz od apostołów w Jerozolimie i nie zostało skierowane wyłącznie do wspólnoty w Koryncie, lecz jest głoszone wszędzie. Dlatego też Paweł sprzeciwia się dążeniu Koryntian do zmiany dyscypliny dotyczącej posługiwania się słowem natchnionym i zachowania się kobiet w zgromadzeniu. Muszą więc oni postępować tak, jak wierni innych wspólnot Kościoła ${ }^{12}$.

Zalecenia więc, które Paweł daje względem kobiet i ich zachowania w zgromadzeniach publicznych i liturgicznych w żaden sposób nie jest wyrazem deprecjonowaniach ich pozycji społecznej. Nie kwestionuje ich pozycji w małżeństwie i rodzinie, a jedynie wskazuje na właściwe korzystanie z darów, które zostały im dane. Taki jest bowiem kontekst wypowiedzi 1 Kor 14:33b-35. Przecież porządek musi obowiązywać zwłaszcza w zgromadzeniach publicznych, a otrzymane od Boga dary winny być używane w sobie właściwy sposób.

10 Por. M. Rosik, Pierwszy List do Koryntian, s. 463-464.

11 Por. J. Czerski, Pierwszy List do Koryntian, s. 647.

12 A. Jankowski, K. Romaniuk, L. Stachowiak, Komentarz praktyczny, s. 754. 


\section{O zachowaniu się kobiet podczas modlitwy}

Wypowiadając się na temat zachowania w czasie modlitwy, Paweł daje instrukcje dotyczące mężczyzn (1 Tm 2,8) i kobiet (1 Tm 2,9-15). Już dysproporcja pomiędzy tymi wskazaniami wskazuje na ważkość problemu, z jakim musiał się mierzyć Kościół w Efezie. Zwróćmy jednak najpierw uwagę na kontekst wypowiedzi. Oto autor listu daje najpierw ogólne wskazanie dotyczące modlitwy $(2,1-2)$. Następnie podaje wymogi duchowe, a nawet podaje wskazówki dotyczące postawy zewnętrznej modlących się, aby ich modlitwa była skuteczna.

$\mathrm{Na}$ pierwszym miejscu więc stawia wymagania wobec mężczyzn, którzy winni zachować „czyste ręce, bez gniewu i sporu” $(2,8)$. Podobne wymagania stawiane są kobietom $\mathrm{z}$ dodatkiem dotyczącym ubioru: „z godnością i rozsądkiem niech się przyozdabiają, nie zaplecionymi włosami i złotem czy perłami, czy drogimi strojami, lecz przez to, co wypada kobietom, które przyznają się do wiary w Boga, dobre czyny" (2,9-10). Pozorna dysproporcja może być wytłumaczona specyficznym kontekstem społecznym funkcjonowania mężczyzny i kobiety. Mężczyźni, na co dzień funkcjonujący w surowym świecie i narażeni na codzienne ciężary życia, winni w czasie modlitwy powstrzymać się od gniewu i sporów, zachowując ręce „czyste” (hosious), to znaczy wolne od krwi i nieczystości ${ }^{13}$. Kobiety zaś w czasie modlitwy winny powstrzymać się od przyozdabiania się czymkolwiek, co nie licuje z ich „przyznaniem się do wiary w Boga" (epangellomenais theosebeian). Co jest takim stosownym strojem? Odpowiedź jest zwięzła i jasna: „dobre uczynki” (diergōn agathōn). Dzisiaj powiedzielibyśmy: Niech w czasie modlitwy będę ubrane stosownie, skupiając się raczej na dobrych uczynkach niż na wystawnych strojach. Podobnie, jak mężczyźni, w czasie modlitwy, mają się powstrzymać od prezentowania swoich zalet płciowych, społecznych i zawodowych.

Zastanawia jednak fakt, dlaczego autor rozszerza swój wywód na temat postawy kobiety? Czy te zalecenia dotyczą jedynie zgromadzenia modlitewnego, czy też mamy do czynienia z odwołaniem się do podwójnego znaczenia terminów gynē („kobieta, żona”) i anēr („mężczyzna, mąż”)? Kontekst wskazywałby na to, że rzecz dotyczy ogólnie mężczyzn i kobiet i ich zachowania w czasie modlitwy (zob. 2,8-10). Wówczas należałoby uznać, że wskazania ustanawiają określone normy prawne w sprawie pozycji kobiety w zgromadzeniu liturgicznym, w którym nie ma ona prawa nauczać, lecz pozostawać „w cichości” - en hessychia(i) $(2,12)$ i w postawie pełnego uniżenia: „Z całym poddaniem” - en

13 Por. S. Cipriani, Lettere Pastorali, s. 85. 
pasē $(i)$ hypotagè $(i)(2,11)^{14}$. Jednak z wypowiedzi $2,11-12$ nie wynika bezpośrednio, że wskazania dotyczą w sensie ogólnym mężczyzn oraz kobiet i postawy tych ostatnich jedynie w zgromadzeniu liturgicznym. Czasownik mathanetō, którym został wyrażony nakaz wobec kobiet, wskazuje na kontekst nauczania. Wydaje się więc uzasadnioną opinia, że mamy do czynienia z modelem nauczyciela i uczniach, podobnie jak w 1 Kor 14,33b-35. „Mężczyzna/mąż” (anēr) byłby wzorcem nauczyciela-mistrza, podczas gdy „kobieta/żona” (gynē) modelem ucznia. Niewykluczone również, że mamy tu do czynienia z oparciem się na podwójnym znaczeniu pojęć anēr i gynē. O ile żona w rodzinie i w małżeństwie posiada określoną, nierzadko uprzywilejowaną pozycję, o tyle kobieta nie mogła mieć takiej pozycji w zgromadzeniu liturgicznym. Przenoszenie władzy domowej na postawę w czasie modlitwy było niedozwolone. Wskazania zatem, o których czytamy w $1 \mathrm{Tm}$ 2,11-12, dotyczą wyłącznie postawy kobiety w czasie zgromadzeń liturgicznych, a nie jej pozycji w rodzinie i społeczeństwie w ogólności. Zatem i w tym przypadku nic nie wskazuje na deprecjonowanie społecznej pozycji kobiety w stosunku do mężczyzny.

Na zakończenie należałoby jeszcze zwrócić uwagę na motywację, jaka została podana przez natchnionego autora. Są to dwa argumenty o charakterze teologicznym. W odniesieniu do aktu stworzenia, stwierdzone zostało pierwszeństwo Adama przed Ewą (Rdz 2,18.21-24). W odniesieniu do historii, kobieta okazała się słabsza, ponieważ to ona została zwiedziona (Rdz 3,4-5.1213). Niewątpliwie tego rodzaju argumentacja odnosi nas do praktyki judaizmu, w którym kobieta nie mogła aktywnie uczestniczyć w zgromadzeniach synagogalnych. Niewykluczone również, że w 1 Tm 2,11-15, podobnie jak we wszystkich Listach Pasterskich, mamy do czynienia ze zdecydowaną polemiką z pewnymi ugrupowaniami gnostyckimi, które przypisywały kobiecie i mężczyźnie identyczne funkcje, a różnice płciowe ograniczają się wyłącznie do sfery fizycznej ${ }^{15}$. Taka opinia była nie do przyjęcia, ponieważ kobietę i mężczyznę różni nie tylko płeć, lecz także specyficzne dla każdego z nich zadania rodzinne, społeczne i religijne. A ich zamiany w żaden sposób nie można nazwać równością.

\section{Podsumowanie}

Kilka uwag końcowych. Wiele elementów przedstawionych przeze mnie tekstów zostało zaczerpniętych z tradycji i zwyczajów społeczności, w której żyli

\footnotetext{
14 Por. ibidem.

15 Por. C. Marcheselli-Casale C., Le Lettere Pastorali, s. 206-2078; por. też S. Cipriani, Lettere Pastorali, s. 86.
} 
ludzcy autorzy Pisma Świętego. Rzeczywiście rola kobiety w czasach Starego Testamentu była naznaczona dominacją mężczyzny. Jednak już w Księdze Rodzaju zauważamy rewolucyjne zmiany, graniczące wręcz ze swego rodzaju rewolucją społeczną. Oto okazuje się, że zarówno w tekście pochodzącym z X w. przed Chr. (Rdz 2,7.21-23), jak i w tym z ok. V w. przed Chr. (Rdz 1,26-27) kobieta w niczym nie ustępuje mężczyźnie. Jest mu całkowicie równa. Obserwując zaś sytuację w Koryncie, na którą Paweł reaguje w bardzo zdecydowany sposób (1 Kor 11,2-16; 14,33b-36), wydaje się, że znów wszystko wraca do „normy”, na rzecz dominacji mężczyzny. Tymczasem tak nie jest. Po pierwsze, reakcja na konkretną sytuację, to znaczy domaganie się od kobiet możliwości wypełniania funkcji kultycznych. Po drugie, uwagi dotyczące zachowania kobiety i mężczyzny w czasie liturgii, zawierają w sobie model idealnego ucznia (kobieta) i idealnego nauczyciela (mężczyzna). Jak wiemy, uczeń słucha tak długo, jak długo jest uczniem. Kiedy przestaje nim być, wówczas przestaje milczeć i stając się nauczycielem, zaczyna mówić. Podobnie rzecz ma się ze wskazaniami zwartymi w 1 Tm 2,11-15. Kobieta jako matka i żona posiadała jasno określoną i uprzywilejowaną pozycję w małżeństwie i w rodzinie. Nie mogła jednak tej pozycji przenosić na zgromadzenie liturgiczne, nawet jeśli odbywały się one w domu, którego właścicielem był jej mąż. Ostateczny wniosek więc jest taki, że patriarchat, jakkolwiek mocno zakorzeniony w judaizmie i z niego zaczerpnięty przez chrześcijaństwo, niekonieczne musi sprzyjać deprecjonowaniu pozycji kobiety w życiu społecznym. Analizowane teksty wskazują raczej na pozycję równą mężczyźnie, jakkolwiek każdy (i kobieta, i mężczyzna) posiadają sobie właściwą pozycję w zgromadzeniu liturgicznym, zależnie od otrzymanych charyzmatów.

\section{Bibliografia}

Brzegowy T., Pięcioksiag Mojżesza, Tarnów 1995.

Cipriani S., Lettere Pastorali, 1-2 Timoteo. Tito. Versione, troduzione, note, Roma 1972

Czerski J., Pierwszy List do Koryntian, Wrocław 2009.

Fabris R., Prima Lettera ai Corinzi. Nuova versione, introduzione e commento, Milano 2005.

Haag H., Schöpfungsbericht, w: Bibel Lexikon (red. H. Haag), Zürich-Köln 1968, 1554. Hergesel T., Rozumieć Biblię, t. I: Stary Testament. Jahwizm, Kraków1990.

Jankowski A., Romaniuk K., Stachowiak L., Komentarz praktyczny do Nowego Testamentu, Poznań-Warszawa 1975.

Marcheselli-Casale C., Le Lettere Pastorali. Le due lettere a Timoteo a la lettera a Tito. Introduzione, versione, commento, Bologna 1995. 
Rosik M., Pierwszy List do Koryntian. Wstęp, przekład $z$ oryginatu, komentarz, Częstochowa 2008.

Stasiak S., Komentarz do Dziejów Apostolskich, Listu do Rzymian, 1-2 Listu do Koryntian i Listu do Galatów (Komentarz teologiczno-pastoralny do Biblii Tysiąclecia. Nowy Testament 2), Poznań 2014.

Zimmerli W., 1. Mose 1-11. Die Urgeschichte, Zürich ${ }^{3} 1967$. 